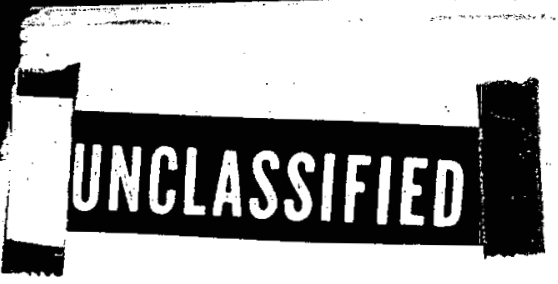

ORNL-1503(Del.)

\title{
METALLURGY DIVISION QUARTERLY PROGRESS REPORT FOR PERIOD ENDING JANUARY 31, 1953
}

\section{LEGAL NOTICE}

This report was prepared as an account of Government sponsored work. Neither the United States, nor the Commission, nor any person acting on behalf of the Commission:

A. Makes any warronty or representation, express or implied, with respect to the accuracy, completeness, or usefulness of the information cantained in this report, or thot the use of any information, apporotus, method, or process disclosed in this report may not infringe privately owned rights; or

B. Assumes any liabilities with respect to the use of, or for damages resulting from the use of any information, apporatus, method, or process disclosed in thits report.

As used in the above, "person acting on behalf of the Commission" includes any employee or contractor of the Commission to the extent that such emplayee or contractor prepares, handles or distributes, or provides access to, any information pursuant to his employment or contract with the Commission.

April 6, 1953

Oak Ridge National Laboratory, Tennessee

UNITED STATES ATOMIC ENERGY COMMISSION

Technical Information Service Extension, Oak Ridge, Tennessee

Photostat Price $\$ \frac{-4.80}{\text { Microfilm Price } \$ 2.50}$
Available from the
Office of Technical Services
Department of Commerce
Washingion 25, D. C.




\section{DISCLAIMER}

This report was prepared as an account of work sponsored by an agency of the United States Government. Neither the United States Government nor any agency Thereof, nor any of their employees, makes any warranty, express or implied, or assumes any legal liability or responsibility for the accuracy, completeness, or usefulness of any information, apparatus, product, or process disclosed, or represents that its use would not infringe privately owned rights. Reference herein to any specific commercial product, process, or service by trade name, trademark, manufacturer, or otherwise does not necessarily constitute or imply its endorsement, recommendation, or favoring by the United States Government or any agency thereof. The views and opinions of authors expressed herein do not necessarily state or reflect those of the United States Government or any agency thereof. 


\section{DISCLAIMER}

Portions of this document may be illegible in electronic image products. Images are produced from the best available original document. 
Controct No. W.7405-eng.26

\author{
METALLURGY DIVISION \\ QUARTERLY PROGRESS REPORT \\ for Period Ending January 31, 1953
}

J. H. Frye, Jr., Director

EDITED BY

W. H. Bridges

DATE ISSUED

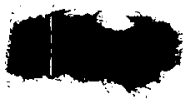

XPF $6 \quad 1953$
OAK RIDGE NATIONAL LABORATORY
Oporated by
CARBIDE AND CARBON CHEMICALS COMPANY A Division of Union Carbide and Carbon Corpotation Post Office Box P
Oak Ridge, Tennessee




\section{SECURITY INFORMATION}

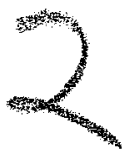

Reports previously is sued in this series are as follows:

ORNL-2B

ORNL 69

ORNL -407

ORNL.511

ORNL.583

ORNL.754

ORNL-827

ORNL-910

ORNL-987

ORNL-1033

ORNL-1108

ORNL-1161

ORNL-1267

ORNL-1302

ORNL-1366

ORNL-1437
Period Ending March 1, 1948

Period Ending May 31, 1948

Period Ending July 31, 1949

Period Ending October 31, 1949

Period Ending Janjary 31, 1950

Period Ending April 30, 1950

Period Ending July 31, 1950

Period Ending October 31, 1950

Period Ending Januory 31, 1951

Period Ending April 30, 1951

Period Ending July 31, 1951

Period Ending October 31, 1951

Period Ending January 31, 1952

Period Ending April 30, 1952

Period Ending July 31, 1952

Period Ending Oetober 31, 1952

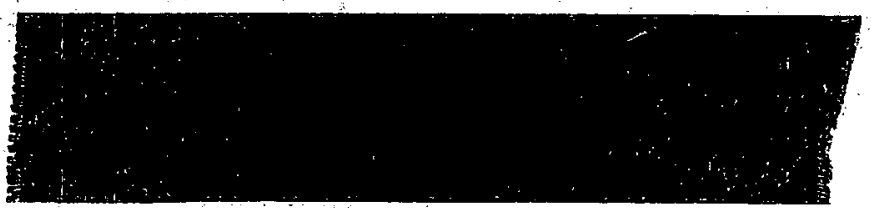




\section{辰 \\ SECURITY INFORMATION}

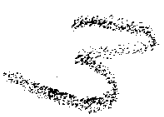

CONTENTS

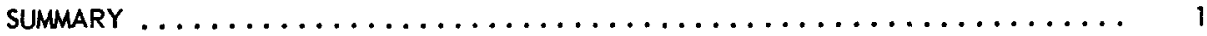

PHYSICAL METALLURGY OF REACTOR MATERIALS $\ldots \ldots \ldots \ldots \ldots \ldots \ldots \ldots \ldots$

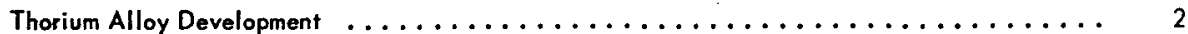

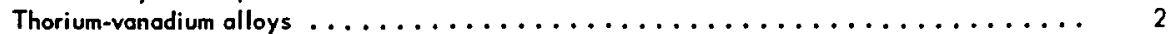

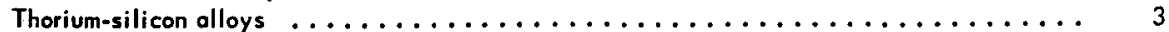

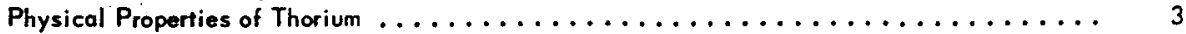

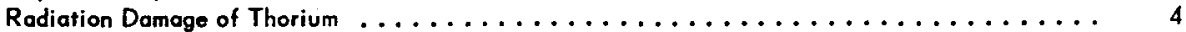

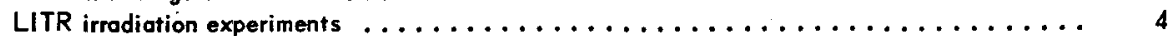

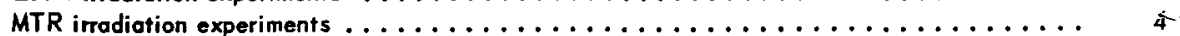

Properties of Pure Metals ......................... 4

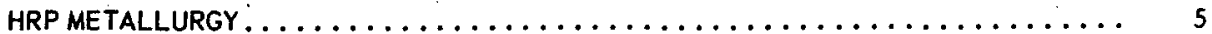

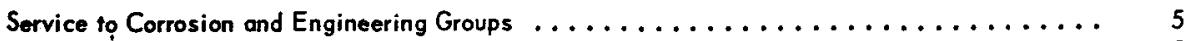

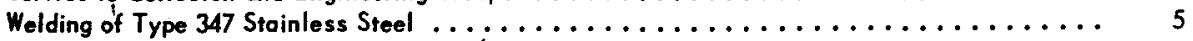

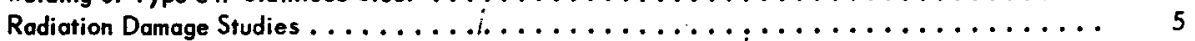

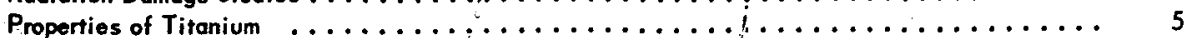

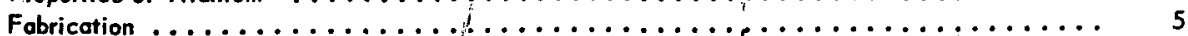

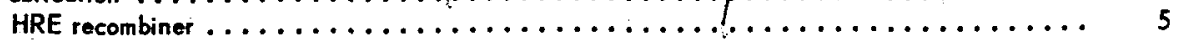

Riveting of second HRE impeller

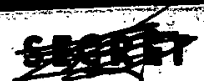 SECURITY INFORMATION}




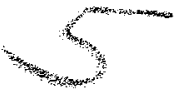

\section{METALLURGY DIVISION QUARTERLY PROGRESS REPORT}

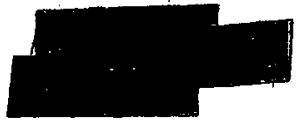

\section{PHYSICAL METALLURGY OF} REACTOR MATERIALS

Investigation of the effect of vanadium additions? (up to $8.5 \%$ ) and silicon additions (up to $0.1 \%$ ) on; the properties of thorium has shown that neither of these is a potent strengthener. The effect of heot treatment on the properties of the vanodium alloys will be investigoted.

Expansivity measurements on thorium have not shown any discontinuity in the temperature range 1325 to $1450^{\circ} \mathrm{C}$, where a sharp increase in electrical resistivity hod been noted previously. Further refined tests are planned.

Rodiation damage tests on thorium specimens are now under woy in the LITR. Specimens of unalloyed thorium and of $99 \%$ Th-1\% $U^{235}$ alloy are being prepared for MTR exposure. 
METALLURGY DIVISION QUARTERLY PROGRESS REPORT

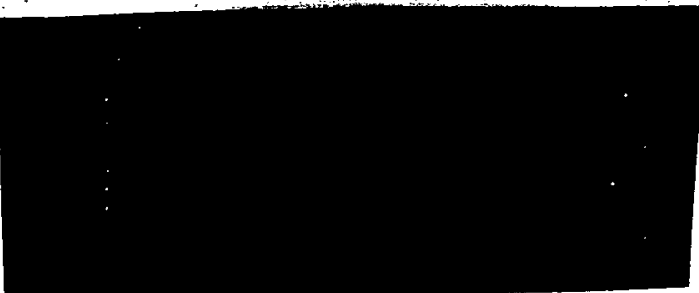

fluoride mixtures and ather combinations

Petrographic investigation of the mononydrate of $\mathrm{UO}_{3}$ is in progress.

\section{REACTOR COMPONENT FABRICATION}

Test work indicates that a ceramic coating containing $10 \%$ boron, developed in the Ceromic Laboratory, can be successfully applied to a thickness of $15 \mathrm{mils}$ on mild steel that is up to $1 / 16$ in. in thickness. A peculiar banding strueture was observed in quartz specimens irradiated with a cobalt source. In the ceramic fuel element studies, annular rings have been formed from a cermet composition contcining $70 \% \mathrm{Cr}-30 \% \mathrm{Al}_{2} \mathrm{O}_{3}$; about $8 \% \mathrm{UO}_{2}$ is included in sondwich form in the compact. Further accomplishments on cercmic fuels include the development of a SiC.Si body by using special techniques; preparation of $\mathrm{USi}_{2}$ bodies; and the development of a design for an in-reactor high-temperature test rig. Work was corried out on the preparation of $\mathrm{ThO}_{2}$ and $\mathrm{UO}_{2}$ bodies intended for reoctor service. An investigation of the vapor decomposition method for the application of coatings to ceramics was started. An investigation was begun on the development of insulating end caps for Hanford-type slugs. A study of the physical strueture of the $\mathrm{BeO}$ blocks wos made as an aid to the interpretation of the deO-NaK compatibility tests.

Petrographic studies included the examination of
- Cladding experiments are in progress to es. tablish the technical feasibility of a reactor design that features the use of thorium. uranium alloy fuel elements. Preliminary work indicotes thot the thorium-rich alloy is easily prepared and con be readily hot or cold worked by conventional methods; also, that the alloy can be metallurgically bonded to both oluminum and $z$ ir conium for construction of flat-plate-type elements. Attempts are being mode to clad the alloy with stainless steel.

Alclad plates with 98.8 wt \% thorium and highly enriched uranium cores have been fabricated and forwarded to the MTR for irradiation testing.

Initial design and fabrication studies to improve the operational performance of the MTR ore complete. Results indicate that a gain in excess reactivity of 3 to $4 \%$ is possible by judicious modifications in design and techniques of manufacturing the fuel elements.

It is proposed to replace the lower stainless steel section in the shim control rod with an aluminum extrusion to reduce fabrication cost. The change will not adversely affect either operational control or the mechanical stabifity of the rod.

\section{PHYSICAL METALLURGY OF REACTOR MATERIALS}

\section{E. J. Boyle}

\section{THORIUM ALLOY DEVELOPMENT}

\section{J. A. Milko}

The alloy development program for improving the corrosion resistance and mechanical properties of thorium has continued. Analyses for the thorium. vanadium alloys, the mechonical properties of which were reported previously, (1) are now avail. fule and ore listed in Table 1.

(1) J. A. Milko, Mer. Div. Quar. Prog. Rep. Oct. 31, 1952, ORNL-1437, o. 4 .
Concurrently with the preparation of thoriumvanadium alloys, alloys of silicon with Ames thorium were prepored by are melting. Results of the effect of small additions of silicon on the mechanical properties of Ames thorium are listed in Table 2.

Thorium-Vanadium Alloys. The effects of vo. nodium on thorium are shown in tho dato of Table 1. Additions of about $0.6 \%$ to $1.2 \%$ of vanadium to thorium seem to lower the hardness and strength properties. This appears to be either. a deoxidation action on the thorium by the vanodium or a 
removal of carbon from a probable solid solution by the formation of vanodium corbide.

Additions of vanadium above about $1.2 \%$ oppear to harden the thorium. However, the rate of hardening, or, for thot matter, of strengthening, is not too marked. Therefore, by disregarding ony probable effects of heat treatment, it moy be con. cluded that vanodium does not appear to be a potent alloying element for thorium.

Thorium-Silicon Alloys. Additions of small amounts of silicon to Ames thorium tend to increose the strength properties and hardness gradually. Ductility, as measured by per cent elongation and reduction of area, is lowered gradually by the addition of small amounts of silicon. The data are presented in Table 2.

It seems desirable at this time for odditional alloys of higher silicon content to be prepared for study. Knowledge of properties of such alloys would be directly opplicable to several problems relating to reactor material design.

\section{PHYSICAL PROPERTIES OF THORIUM}

R. E. Adams

Previous work indicated that a sharp inerease in the electrical resistance of thorium occurs in the

\section{TABLE 1. EFFECT OF VANADIUM ON THE PROPERTIES OF AMES THORIUM}

Annealed for $1 / 2 \mathrm{hr}$ of $750^{\circ} \mathrm{C}$ oiter cold swoging about $50 \%$

\begin{tabular}{|c|c|c|c|c|c|c|c|c|}
\hline \multicolumn{3}{|c|}{ CHEMICAL COMPOSITION (\%) } & \multirow{2}{*}{$\begin{array}{l}\text { TENSILE } \\
\text { STRENGTH } \\
\text { (DSi) }\end{array}$} & \multirow{2}{*}{$\begin{array}{c}\text { YIELD STRENGTH } \\
\text { AT } 0.2 \% \text { OFFSET } \\
\text { (psi) }\end{array}$} & \multirow{2}{*}{$\begin{array}{l}\text { PROPORTIONAL } \\
\text { LIMIT } \\
\text { (psi) }\end{array}$} & \multirow{2}{*}{$\begin{array}{l}\text { ELONGATION } \\
\text { IN } 1.5 \mathrm{in.} \\
\text { (x) }\end{array}$} & \multirow{2}{*}{$\begin{array}{l}\text { REDUCTION } \\
\text { OF AREA } \\
\text { (x) }\end{array}$} & \multirow{2}{*}{$\begin{array}{l}\text { ROCKWELL } \\
\text { HARDNESS }\end{array}$} \\
\hline$v$ & $c$ & $T_{h}^{(0)}$ & & & & & & \\
\hline 0.39 & 0.038 & Balence & $30,900^{(b)}$ & $20,000^{(b)}$ & $16,200^{(b)}$ & $47.0^{(b)}$ & $57.0^{(b)}$ & 78 \\
\hline 0.59 & 0.036 & Balance & $29,300^{(c)}$ & $17,900^{(c)}$ & $13,700^{(c)}$ & $57.0^{(c)}$ & $64.0^{(t)}$ & 65 \\
\hline 1.17 & 0.033 & Bolonce & $27,400^{(c)}$ & $16,600^{(c)}$ & $13,700^{(c)}$ & $51.0^{(c)}$ & $82.0^{(d)}$ & 75 \\
\hline $3.33^{(e)}$ & $0.040^{(e)}$ & Balance & $33,600^{(d)}$ & $16,300^{(d)}$ & $11,400^{(d)}$ & $34.0^{(d)}$ & $55.0^{(d)}$ & 81 \\
\hline $6.30^{(*)}$ & $0.087^{(0)}$ & Balonce & $39,500^{(b)}$ & $20,400^{(b)}$ & $12,100^{(b)}$ & $26.0^{(b)}$ & $40.0^{(b)}$ & 93 \\
\hline 8.54 & 0.042 & Bolance & $36,700^{(b)}$ & $20,200^{(b)}$ & $12,700^{(b)}$ & $28.0^{(b)}$ & $50.0^{(b)}$ & 100 \\
\hline
\end{tabular}

(a) Also contains trace impurities of $\mathrm{Be}, \mathrm{Al}, \mathrm{Fe}, \mathrm{N}, \mathrm{Co}, \mathrm{Mg}, \mathrm{B}, \mathrm{Cd}$, and $\mathrm{Zn}$.

(b) Average of four tests.

(c) Average of three tests.

(d) Average of two lests.

(e) Values appear to be high and will be checked.

TABLE 2. EFFECT OF SILICON ON THE PROPERTIES OF AMES THORIUM

Annealed for $\frac{l}{2}$ thr of $750^{\circ} \mathrm{C}$ after cold reduction of about $85 \%$

\begin{tabular}{|c|c|c|c|c|c|c|c|c|c|}
\hline \multicolumn{3}{|c|}{ CHEMICAL COMPOSITION (\%) } & \multirow{2}{*}{$\begin{array}{c}\text { TENSILE } \\
\text { STRENGTH } \\
\text { (psi) }\end{array}$} & \multirow{2}{*}{$\begin{array}{c}\text { YIELD STRENGTH } \\
\text { AT 0.2\% OFFSET } \\
\text { (psi) }\end{array}$} & \multirow{2}{*}{$\begin{array}{c}\text { PROPORTIONAL } \\
\text { LIMIT } \\
\text { (psi) }\end{array}$} & \multirow{2}{*}{$\begin{array}{l}\text { ELONGATION } \\
\text { IN } 2 \text { in. } \\
\text { (x) }\end{array}$} & \multirow{2}{*}{$\begin{array}{l}\text { REDUCTION } \\
\text { OF AREA } \\
\text { (x) }\end{array}$} & \multicolumn{2}{|c|}{ HARDNESS } \\
\hline$S_{i}$ & c & $\mathrm{Th}^{(\mathrm{o})}$ & & & & & & Rockwoll H & VHN \\
\hline 0.032 & 0.032 & Balance. & $25,700^{(b)}$ & $15,000^{(b)}$ & $9,600^{(b)}$ & $51.0^{(b)}$ & $54.0^{(b)}$ & $89(c)$ & $65^{(c)}$ \\
\hline 0.077 & 0.037 & Bolonce. & $27,700^{(b)}$ & $16,700^{(b)}$ & $11,000^{(b)}$ & $4.0^{(b)}$ & $54.0^{(b)}$ & $94^{(c)}$ & $72^{(c)}$ \\
\hline $0.110^{\circ}$ & 0.041 & Batance. & $29,800^{(b)}$ & $18,700^{(b)}$ & $12,700^{(b)}$ & $12.0^{(b)}$ & $48.0^{(b)}$ & $95^{(c)}$ & $72^{(e)}$ \\
\hline
\end{tabular}

(a) Also contains trace impuritios of $\mathrm{Be}, \mathrm{Al}, \mathrm{Fo}, \mathrm{N}, \mathrm{Co}, \mathrm{Mg}, \mathrm{B}, \mathrm{Cd}$, and $\mathrm{Zn}$.

(b) Average of two tests.

(c) Average of ten readings. 
temperafure range of about 1325 to $1450^{\circ} \mathrm{C}$. In an effort to ascribe a reason for this, investigations ore being mode to learn whether any other properties of thorium undergo changes in this temperature region.

Preliminary experiments have been made to measure the coefficient of thermol exponsion of thorium of high temperatures. The dota obtoined thus far indicate that no significant discontinuities occur in the thermal expansion vs. temperature curve between about 900 and $1600^{\circ} \mathrm{C}$. Since the test methods were somewhat crude, the coef. ficients of expansion of thorium are not accurately known. Some improvements in technique have been adopted, and later tests with iron hove indicated that the phase transformation between alpha and gammo iron, and between gamma and delto iron, are clearly indicated. Additional tests with tho. rium will be made in the near future.

\section{RADIATION DAMAGE OF THORIUM}
R. E. Adams
R. H. Kernohon (2)

A study of the effects of neutron irradiation on the properties of thorium is being carried out. Although no information has been obtained from these experiments, as yet, the status and scope of the program will be described here.

LITR Irradiation Experiments. Several thorium test specimens are now being irradiated in the LITR at an approximate flux of $4 \times 10^{12}$ neu. trons $/ \mathrm{cm}^{2} \cdot \mathrm{sec}$. A detailed description of the specimens was given in ORNL-1366. ${ }^{(3)}$ Irradiation of the cylindrical and the hardness test specimens started on August 19, 1952, and the tensile and impoct specimens were put in the reactor on De. cember 1, 1952. The specimens will be exposed for six months.

MTR Irradiation Experiments. Plans have also been made for irradiation of thorium in the MTR. Specimens will be irradioted at o flux of about $10^{14}$ neutrons $/ \mathrm{cm}^{2} \cdot \mathrm{sec}$. One set of specimens will be exposed for six months; a duplicate set

(2) Solid State Division.

(3) R. E. Adams, Met. Div. Quar. Prog. Rep. July 31 1952, ORNL.1366, p. 10. will be exposed for one year. The specimens will be canned in copsules containing liquid NoK to provide good heat transfer between the specimens and the copsule walls.

Each set of specimens will contain the following samples:

1. two cylindrical test specimens, $0.204 \mathrm{in}$. in diameter and $4 \mathrm{in}$. long, which will be used to study changes in dimensions, dynomic elastic modulus, electrical conductivity, and thermal conductivity;

2. four impoct test specimens, 0.204 in. in diameter and $4 \frac{3}{4}$ in. long, each of which can be broken in four ploces;

3. twelve hardness test specimens, $0.204 \mathrm{in}$. in diameter and $1 / 8$ in. thick, which are for study of changes in hardness and possible effects of postirradiotion annealing.

A test program is also being planned for investigating the effects of irradiation damage in thorium containing $\mathrm{U}^{235}$ as an alloying addition.

Tentatively, it is planned to irradiate a $99 \%$ Th$15 U^{235}$ alloy, and to approximately duplicate the present experiments scheduled for MTR irradiation.

\section{PROPERTIES OF PURE METALS}

$$
\text { W. J. Fretogue }
$$

The Mechanical Testing group hos performed elevoted-temperature tensile tests on specimens made from six induction-melted nickel rods, which were described in a previous report. ${ }^{(4)}$ Variations in the impurity content of the individual melts affected the physical properties of the material to such a degree as to make the data non interpretable for the purpose for which the experiments were designed. A purchose order hos been placed with the Vacuum. Metals Corp. for $20 \mathrm{ft}$ of $7 / 8$-in.-dia "Nivac" (high-purity, gas-free nickel). This moterial is produced in $200-16$ ingots, and therefore it is possible to obtain specimens that are more homogeneous than those obtained from individual melts. When this meterial is delivered the experiments will be repeoted.

(4)W. J. Fretague, Met. Div. Quar. Prog. Rep. July 31 , 1952, ORNL-1366, P. 10. 


\title{
15.
}

\section{HRP METALLURGY}

\author{
W. J. Fretogue \\ E. C. Miller

\section{W. J. Leonard}

\section{SERVICE TO CORROSION AND ENGINEERING GROUPS}

Examination of a sample holder of type 304 stainless steel has established the susceptibility of a sensitized, austenitic, stainless steel to intergranular corrosion attack in uranyl sulfate contoining $100 \mathrm{~g}$ of uranium per liter at $100^{\circ} \mathrm{C}$ under crevice corrosion conditions that involved oxygen depletion of the solution.

A variety of samples of stainless steels have been prepared for the Static and Dynamic Corrosion Test groups in on effort to establish the effect of such metallurgical variobles as mechanical work. ing, heat treatment, and vorious descaling procedures. .

Valve parts of titonium and special stainless steels hove been subjected to hard-surfacing treatments, exposed to corrosion conditions in dynamic corrosion loops, and evaluated metallurgically. This work is continuing because completely satisfactory treatments have not been established.

\section{WELDING OF TYPE 347 STAINLESS STEEL}

Experimental work has been carried on in the welding of thick plates of type 347 stainless steel by using various combinations of passes, by using bare rod filler metal in the inert-gas shielded-arc method, and by using coated electrodes in the conventional, metal-arc welding method. Similar work hos been done in the welding of type 347 stainless steel to a boiler grade of carbon steel. Tentative procedural specifications and a welder's qualification outline have been witten for the heavy-section welding of type 347 stainless steel.

\section{RADIATION DAMAGE STUDIES}

Assistance has been given to the Solid State Division in the selection and preparation of impoct specimens for exposure in the Odk Ridge graphite reactor and in the LITR. The materials prepared included several carbon steels, austenitic stoinless steels, and titanium of various grades.

\section{PROPERTIES OF TITANIUM}

Vacuumafusion analyses and impact tests hove been performed on specimens of commercial-purity fitonium, as well as on high-purity iodide titanium: - as machined, as exposed to uranyl sulfate under static and under dynamic corrosion conditions, and after cothodical treatment - for the purpose of investigating the possibility of contamination and embrittlement by hydrogen during the course of reactor operation.

The limited results available to date are en. couraging in that they do not indicate that uranyl sulfate corrosion adds any appreciable amount of hydrogen to commercial-purity tifonium or that it becomes ony more embrittled as a result of the corrosion. It should be remembered, however, that the tests are not sufficiently complete to be con. clusive and that the commercial-purity titanium was rother brittle even before the efforts to introduce hydrogen.

\section{FABRICATION}

\section{E. S. Bomar}

HRE Recombiner. Operation of the HRE results in a continuous dissociation of the heavy-water moderator into deuterium and oxygen. One method of recombining these gases for refurn to the reactor makes use of a contralled catalytic reaction to reform heavy water. J. Ransohoff of the Reactor Experimental Engineering Division suggested the possibility of applying the catalyst to a metallic surface, which could serve as the high-temperature side of a heat exchanger. The need for a large reacting area led to the work described below.

The structure of metal built 'p by using a wire or powder spray gun is inherently porous and has a relatively rough finish. Since these properties provide increased surface orea, it was decided to investigate the possibilities of these methods of fabrication. Experimental lengths of $1 / 4-i n .-O D$ tubing were prepared by spraying stainless steel on stainless steel tubing to a thickness of 0.010 inch. Bends of $180 \mathrm{deg}$ caused separation of the sprayed loyer from the tube. To minimize this, a thin loyer of a brazing alloy was applied to the tube before spraying.

Approximately 0.005 in. of Nicrobraz alloy wos applied to the tube by using a powder pistol. This
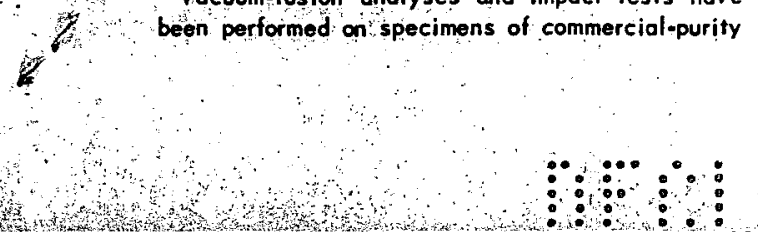


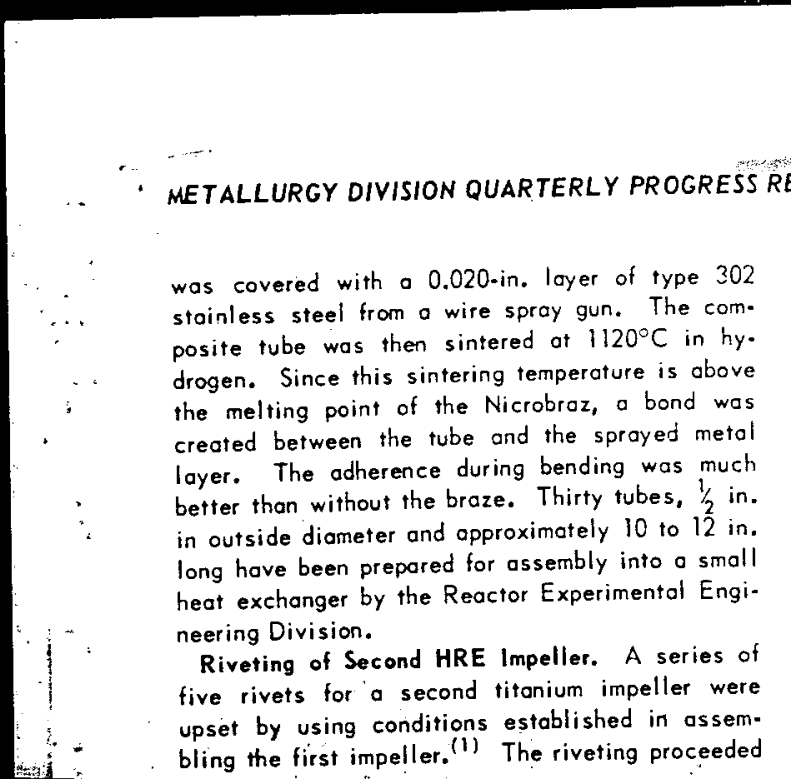

\section{$f p^{2 y^{2}}$}

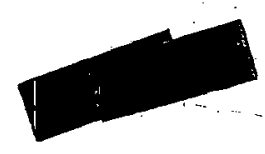

PORT the sprayer metal atter than without the braze. Thirty tubes, $1 / 2$ in. thide diameter and approximotely 10 to 12 in. ong have been prepared for assembly into on si-

whout difficulty; and all rivets upset in a satis-

factory manner, as indicated by a subsequent

cleanup machining operation. All of the rivets were of the some length. The conditions for riv.

eting are given in the following:

Rivet length, in. $13 \%$

Rivet distance, in. 0.178

Voltage on electrodes

Current, \%

Time in cycles

(1)E. S. Bomar, Met. Div. Quar. Prog. Rep. July 37, 1952, ORNL-1366, P. 18. 


\section{CERAMICS RESEARCH}

J. M. Warde
C. E. Curtis
J. R. Johnson
L. M. Doney
A. J. Toylor
S. D. Fulkerson
G. D. White
J. A. Griffin

T. N. MeVay, Consultant

nsultant

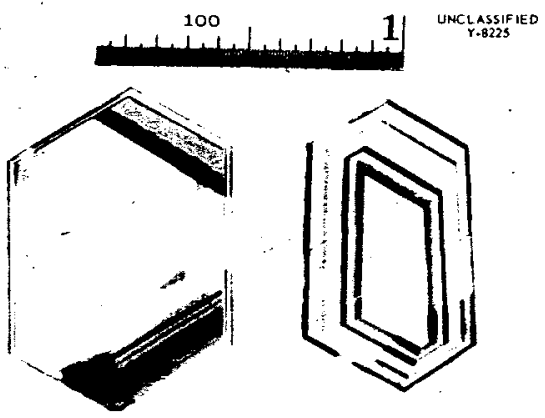

Fig. 17. Quartz Specimens After Irrodiation with - Cobolt Source. Specimen on right from Brazil; specimen on left from Arkansas.

\section{DEVELOPMENT OF CERMETS FOR REACTOR COMPONENTS}

The $\mathrm{Cr}-\mathrm{Al}_{2} \mathrm{O}_{3}$ cermet fabrication studies have esulted in the successful preparation of disks in. in diameter and $20 \mathrm{mils}$ thick. Several sandich disks were also made that contained o thin pyer of $\mathrm{UO}_{2}$ mixed with $70 \% \mathrm{Cr}-30 \% \quad \mathrm{Al}_{2} \mathrm{O}_{3}$. nnular rings have been formed of the $70 \% \mathrm{Cr}-30 \%$ ${ }_{2} \mathrm{O}_{3}$ composition containing about $8 \% \quad \mathrm{UO}_{2}$ in ndwich form. Inveactor tests of these cermets now being contemplated. A $\mathrm{Zr}_{r} \mathrm{C}-\mathrm{Fe}$ cermet was

\section{RADIATION DAMAGE STUDIES}

Further work in the radiation damage studies awaits the results of exposures of ceramic specimens at Hanford. Some additional studies of the banding observed in specimens of quartz irrodiated with a cobolt source were made (Fig. 17). It is believed that these bands are f-center phenomeno resulting trom trace impurities in the quartz. It - is: possible that some correlation of geologic history with the size and nature of the bands moy Ge found. fabricated as a possible material for pump parts, seals, and bearing moterials. This cermet, along with Kennametal 151-a, has been tested for cor. rosion resistance in fluorides, sodium, and lead. These materiols oppear to be very promising. The Kennametal 151-a showed no attack of $800^{\circ} \mathrm{C}$ for $100 \mathrm{hr}$ in sodium, leod, and fluoride No. 14. A slight surface leaching was observed on the $\mathrm{ZrC}$ Fe cermet in both sodium and fluoride No. 14.

The development of fuel elements using combinations of SiC-Si and USi ${ }_{x}$ wos storted. The SiC-Si body is prepared by heating at $1000^{\circ} \mathrm{C}$ for $1 \mathrm{hr}$ o

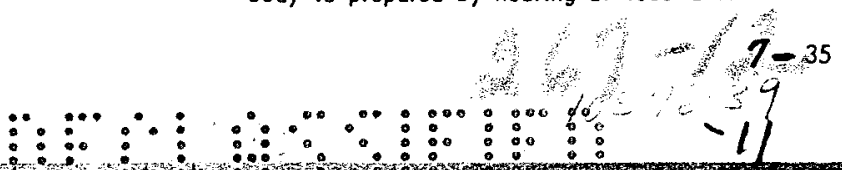


mixture of $50 \%$ graphite (2 micron) and $50 \%$ wheot flour. The resulting porous body is then ploced in a graphite container together with powdered silicon, and the container is heated by resistance to $2000^{\circ} \mathrm{C}$, at which temperature silicon carbide is formed, with an accompanying exothermic reaction, while molten silicon is simultaneously absorbed by the body. The resulting cermet ap. pears to have a well-bonded structure that is free from voids. Further work is in progress to determine the physical properties of this material.

An investigation of the preparation of USi has commenced. A material containing cbout $90 \% \mathrm{USi}_{2}$, $5 \% \mathrm{USi}_{3}$, and $5 \% \mathrm{UO}_{2}$ has been successfulty prepared by heating uranium metal in contact with silicon at $1700^{\circ} \mathrm{C}$. It is necessary to have a very pure argon or helium atmosphere for this reaction.

Preliminary designs of an in-reactor high-temper. ature test rig were mode. It is proposed that a design be prepared for a small chamber about 4 in. in outside diameter and $12 \mathrm{in.}$ long with two concentric compartments; the inner compartment will be for containing ceramic fuels, and the outer compartment will contain water cooling coils that will serve to cool both the contoiner and any hot gases from the inner fuel element chomber. The following gas cycle is to be used: out-ofereactor pump to inner chamber to outer chamber to out-ofreactor radiooctive counting rig to out-of-reactor pump. The out-of-reactor pump is to be used to provide flow rotes over the fuel element of the order of 200 fps.

\section{OXIDE CERAMICS}

Thorium Oxide. In determining the properties of thorium oxide for possible application as a reactor material, it was shown that firing temperatures of 1400 and $1600^{\circ} \mathrm{C}$ (held for $1 \mathrm{hr}$ ) are insufficient to vitrify pure thorium oxide. Firing at $1800^{\circ} \mathrm{C}$ and the effects of additions of olumina, silica, zirconia, and of other ingredients in promoting vitrification at lower temperatures are being investigated. Measurements of the resistance of thoria to autoclaving are being conducted through R. B. Briggs' HRE Group, with the use of fused thoria pellets obtained by this laboratory from the Norton Company.

Three tharia cylinders (solid) $2 \mathrm{in}$, high and $1 \mathrm{in.}$ in diometer were slip-cast and fired at $1600^{\circ} \mathrm{C}$ for the Experimental Engineering Deportment. The cylinders are to be used in testing the thermal conductivity of thorium oxide at room temperature.
Uranium Oxide. Hot-pressed specimens of uranium oxide have been transmitted to R. B. Briggs, HRE Group, for autoclave testing.

\section{FABRICATION OF SPHERES FROM CERAMIC MATERIALS}

A laboratory method for producing small ( $\frac{1}{8}$ to $1 / 2$ in. in diameter) spheres from powdered ceramic moterials is being worked out. This technique will be employed for the production of uronium oxide pellets. and will be usefut for various other applictions.

\section{VAPOR COATING OF BERYLLIUM OXIDE}

The coating of graphite by the vapor decompo. sition method has been described by Kertesz et al.(1) Because hot-pressed beryllium oxide sam. ples hove, in the past, shown o tendency toward particle disintegration when dynamically tested in liquid NoK, it was thought that a coating of silicon, silicon carbide, or some of the rofractory metals might retard, if not completely stop, this disintegration. Accordingly, an apparatus for vapor deposition experiments has been rigged and on investigation commenced under the ioint auspices of the Ceramic Laboratory and the Chemistry Section. So far, it hos been essoulished that hot. pressed beryllium oxide specimens can be cooted by this method by passing $5 \mathrm{iCl}_{4}$ vapor in a hy. drogen atmosphere over hecfed specimens of be. ryllium oxide. It was found that uniess the speci. men temperature is kept in the range 900 to $950^{\circ} \mathrm{C}$, and the flow of vapors is kept ot a very low rate. the cooting is deposited too rapidly and it is 100 thick arid too-uneven. Such a coating spalls off readily, when cooling. For silicon carbide coútings, in the preparation of which $\mathrm{SiCl}_{4}$ and tydrogen vapors are first bubbled through liquid toljene and then passed over the heated sample, the same operating conditions hold. This popping off of the heavy cooting is due, in part, to the wide difference in the coefficients of exponsion of the materials involved. A specimen of silicon that was successfully coated with a thin and uniform cooting was submitted

or a 2UW-hr dynamic test in liquid NaK. Results of this test ore not yet available. Also, a specimen of beryllia presumably (1) F. Kertesz, H. C. Brossfield, and L. M. Doney,
Cooting Graphite with Silicon and with Silicon Corbide by the Vopor Decomposition Method, NEPA.1553 (Aug. 1:

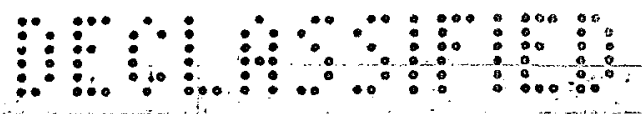


coated with silicon carbide has been submitted for x-ray defermination. It is planned to try coatings of zirconium, molybdenum, titanium, deposited in a similar manner, by using a volatile compound of these metals as a source.

\section{INSULATING END.CAP DEVELOPMENT}

Work has commenced on developing insulated end caps for Hanford-type slugs. It is proposed to fasten disks of ceramic materials inside of the aluminum end caps during the slug canning operation. The purpose of the caps will be to equalize the heat flow from the center of the slug to the surface. A number of disks of various ceramic moterials, such as $\mathrm{SiO}_{2}$ glass, forsterite, zircon, and alumina porcelain, have been prepared. These disks are 30 mils thick and 1.1 in. in dianieter. It was originally intended to make up canned slugs with the ceramic disks in place and forwoyd them to Hanford for tests. Unfortunately, the Y.12 canning line has been shut down and the expense of setting up to get the job done here is prohibi. tive. The disks have therefore been sent to Han. ford for make-up of the slugs.

\section{UNIFORMITY OF BERYLLIUM OXIDE BLOCKS}

A study of the physical struature of the beryllium oxide blocks to be used was made to aid in the interpretation of BEO-NaK compatibility test data. These blocks, fabricated by the Norton Company, were made by hot-pressing beryllium oxide powder. They are hexagonal blocks $2 \frac{1}{8}$ in. on a side, $3^{1} \frac{1}{16}$ in. in diameter across the center of the foces, and 6 in. long. They ore fabricated with a center hole running axially through the block; the diameter of the hole (depending on the position of the block in the reactor core) is $1 / 2$. $1 \frac{1}{8}$ or $1 \frac{3}{4}$ inches. A visual examination was made of about 30 blocks of the type having a K-in.-dia hole. These blocks had boen sawed in two on a plane perpendicular to the long axis.' It was ob. served that in all cases the core of the blocks had a different physical structure than that of the outer portion of the some blocks. In order to study the core structure, six blocks that had not been sowed were sooked in fuchsin dye for 12 hours. The dye is absorbed most in the more porous areas in the block; Fig. 18 shows the typicgl soft-core struce ture roted in oll the dyed specimens. Samples taken from the inside and outside surfaces of these blucks showed density variations from 2.80 to 2.83 st the outside, which decreased to 2.26 to 2.43 of the inside. The apparent porosity of the dense portion of the block is practically zero, compared with values up to $23.3 \%$ for the soft core. Table 25 gives results of density, apparent porosity, and water absorption measurements for specimens cut from various portions of the block.

Blocks that have a $1 \frac{1}{8}$-in.-dia central hole are being split longitudinully so that the two halves can be placed around a cooling pipe. With the blocks split, a large omount of inner surface will

TABLE 25. DENSITY, POROSITY, AND WATER ABSORP TION MEASUREMENTS OF VARIOUS SECTIONS OF THE BERYLLIUM OXIDE BLOCK

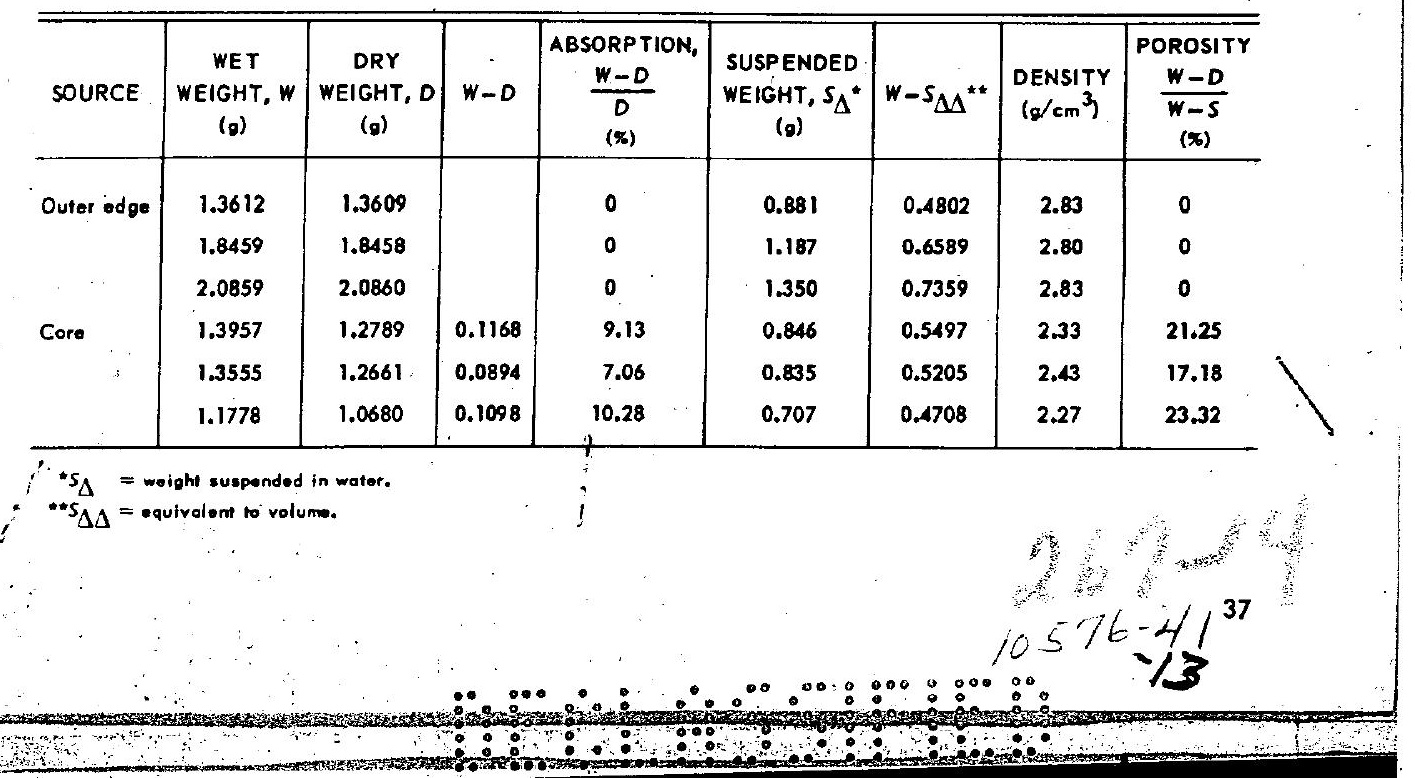




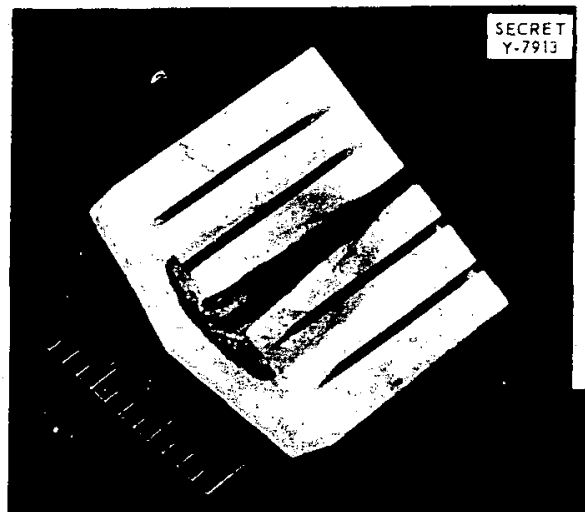

top and bottom punches around the central pin, which would cause binding and therefore uneven pressure application. A further foctor is foulty filling of the die, which would cause bridging of the powder around the pin. Other factors, such os too short time of application of pressure, too short time of holding of pressing temperature, uneven temperature distribution in the beryllium oxide powder because of too rapid heating, cooling of the die to room temperature without extracting the core pin, etc., could also have affected the final density.

Fig. 18. Dye-treated Beryllium Oxide Bloc Showing Porous Central Section.

be exposed to the coolant material. This inne surface is low-density material that is particularl susceptible to NaK corrosion. To determine th extent of the low-density region, a random sampl of these blocks was sooked in fuchsin dye fo $12 \mathrm{hr}$ and specimens were cut from selected locali ties in the block. Figure 19 shows the density and per cent porosity placed on the block in the location from which the somple wos taken. The dark shoded areas on the right of the block indicat. the porous portions shown up by the penetration of the dye. Five samples of blocks with a $1 \frac{3 / 4}{4}-$ in. dia centrat hole were soaked in dye and were alsc found to have a porous central core.

A general observation wos made regarding the prevalence of cracks in all the blocks examined. All the blocks have at least one crock, and some blocks contain several cracks. In some cases these crocks ore visible at the surface of the block, but in the majority of the blocks the cracks are confined to the interior portion. These cracks are quite narrow and contribute only slightly to the porosity. The presence of one of these cracks may be observed in Fig. 19.

The porous condition developed in the hotpressed beryllium oxide blocks is a defect caused by fabricotion. A probable couse of the defect is that the hot-pressed die had too tight a fit on the 


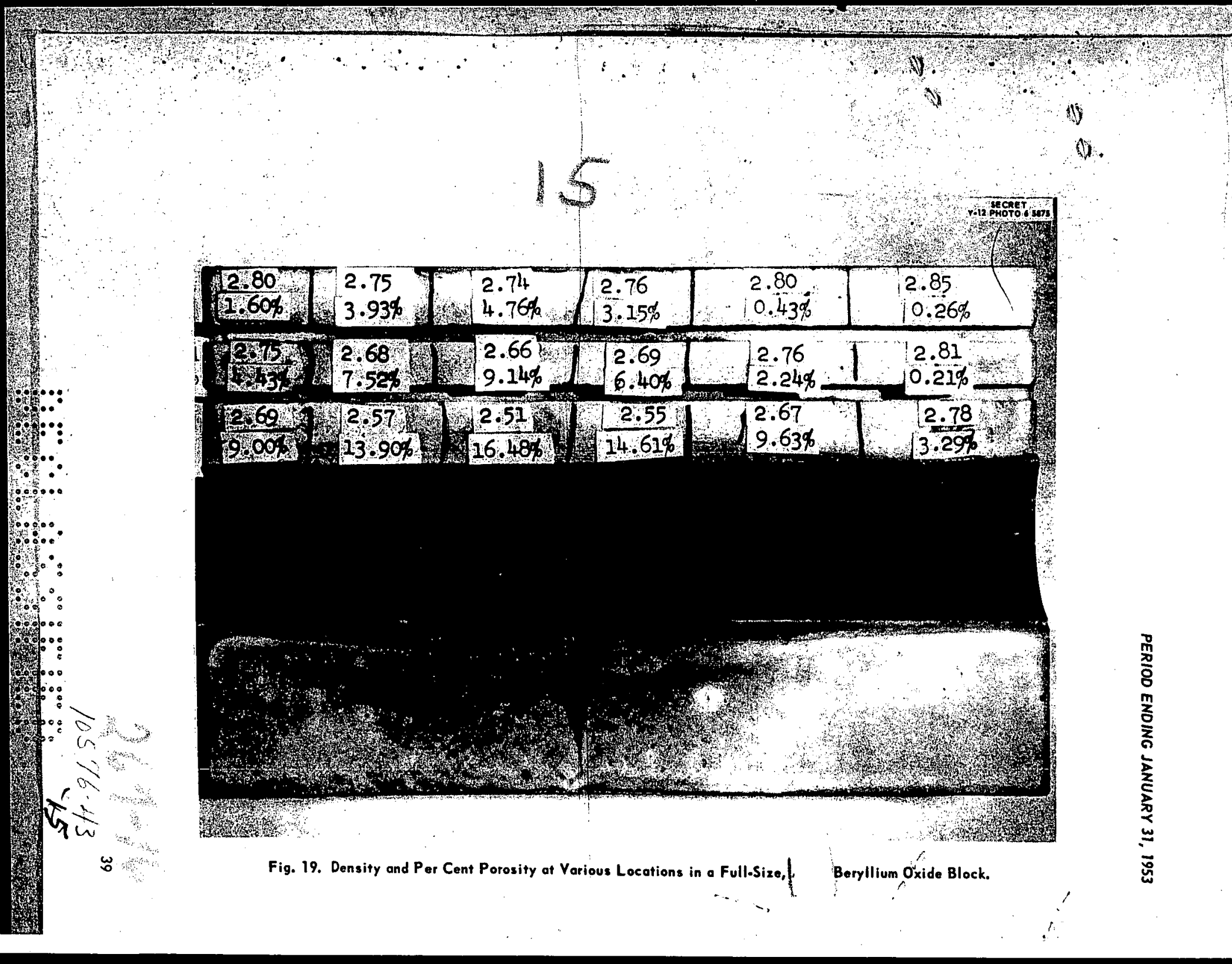


core thickness is believed to be due to the difference in plasticity between the two materials of rolling temperatures.

This defect can be partly corrected by using either $24 \mathrm{ST}$ - or $52 \mathrm{~S}$ :grode aluminum to bock up or stiffen the $2 \mathrm{~S}$-grade aluminum cladding. However, this results in either a 5. or 7.ply sandwich, depending on whether or not 25 -grade aluminum is desired as the outer cladding material.

Three Alclad, enriched, uranium-thorium alloy plates, 8 in. long, I in. wide, and $0.072 \mathrm{in.} \mathrm{thick,}$ and one plate $28 \mathrm{in}$. long, $1 \mathrm{in}$. wide, and $0.072 \mathrm{in}$. thick, were fabricated for irradiation testing in the MTR. The alloy core used in the preparation of these plates was composed of $98.8 \%$ thorium and $1.2 \%$ highly enriched uranium metal.

The cladding techniques developed and proved to be successful for cladding Ames thorium metal with zirconium were tried on a $4 \%$ uranium-thorium alloy. The brazing and the diffusion-anneal cladding techniques appear to work equally well on this thorium-rich alloy.

The brazing-in-vocuum technique, in which o brazing alloy of $22 \%$ zirconium-thorium alloy is used, was fully described in a previous report. (1) The diffusion-anneal method consists of picture framing the alloy in zirconium and conning the entire compact in a stainless steel jacket for oxidation protection during hot rolling. After evacuation through an exhaust tube, the assembly is sealed by hot forging. The use of NBS ceramic frit A-418 caated on the stainless steel prevents the formation of the iron-zirconium eutectic during the diffusion-anneal treatment.

\section{FABRICATION OF URANIUM-ALUMINUM ALLOY COMPONENTS}
J. H. Erwin
G. D. Goldston
J. N. Hix
H. J. Wollace
G. E. Cooley
W. W. Proaps

E. R. Turnbill

MTR Experimental Studies. Work on the problem of improving the operational performance of the MTR continues. Techniques have been found that minimize the omount of poisonous brazing flux entrapped in the fuel element during manufacture.

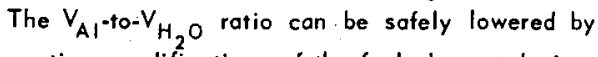
coutious modifications of the fuel element design.

(1)J. E. Cunníngham et ol., Met. Div. Quar. Prog. Rep. suly 31, 1952, ORNL-1366, p. 14.
The proposed substitution of an aluminum extrusion for the lower stainless steel bearing section in the shim control rod will not adversely affect either operational control or the mechanical stability of the rod.

Results of this work were discussed in detail with members of the Phillips Petroleum Co. and the Idaho Operations Office at a meeting held in December. ${ }^{(2)}$ Recommendations were (1) that one control rod of the new design be constructed and tested at ORNL, (2) that an experimental loading of 23 , thin, side-plate units be fabricated according to the latest techniques to be ready for the next reloading on about February 1,1953 , and (3) that the Phillips Petroleum Co. investigate a fuel assembly design that features more fuel concen. trated in the upper half of the element than in the lower half.

Studies to Eliminate Flux Entrapment. Although not known with certainty, it was strongly suspected that the fuel element was being poisoned by simple mechanical entrapment of brazing flux, and experimental work on the problem of removal followed this lead. Another possible mechanism was that of lithium alloying with the oluminum-silicon braze metal in much the same monner that sodium is used to modify this porticular alloy.

Experimental work was conducted in two steps. The initial phose consisted of investigating the effect of higher brazing temperature, joint design, and techniques of applying the flux. No attempt was made to alter the composition of the flux. This work is now complete and the important results are summarized in Table 27.

All tests were run on full-sized, dummy, aluminum fuel units. After brazing, the units were carefully dissolved by the Chemical Technology Division and the solution was analyzed for lithium content by the flame photometer method. The accuracy of the determination is better thon $2 \mathrm{ppm}$ at a $95 \%$ confidence level. In all but the first test, brazing flux from the same batch was used to remove the variable of change in flux composition. Analysis showed thot this flux contained $4.72 \%$ lithium and $54.0 \%$ chlorine.

The omount of chlorine and flux, contained in each unit (shown in Table 27) was calculated on the basis of the above analysis. The use of mercuric nitrate as a catalyst in the dissolving

(2) J. E. Cunningham, MTR Fuel and Control Rod Element Meeting, ORNL CF-53.1.150 (Jan. 14, 1953). 
TABLE 27. RESULTS OF BRAZING TESTS TO ELIMINATE FLUX ENTRAPMENT

\begin{tabular}{|c|c|c|c|c|c|c|c|c|}
\hline \multirow{2}{*}{$\begin{array}{c}\text { TEST } \\
\text { ASSEMBLY }\end{array}$} & \multicolumn{2}{|c|}{ BRAZING CYCLE } & \multicolumn{3}{|c|}{ AMOUNT PER UNIT $(g)$} & \multicolumn{3}{|c|}{$\begin{array}{l}\text { CALCULATED LOSS IN } \Delta k / k \\
\text { IN ACTIVE LATTICE DUE TO }\end{array}$} \\
\hline & $\begin{array}{c}\text { Temperoture } \\
\left({ }^{\circ} \mathrm{F}\right)\end{array}$ & $\begin{array}{l}\text { Time } \\
(\min )^{\prime}\end{array}$ & Li & $\mathrm{Cl}$ & Flux & Li & $\mathrm{Cl}$ & $\mathrm{Li}+\mathrm{Cl}$ \\
\hline$x-1$ & 1100 & 37 & 1.26 & 14.41 & 26.69 & 2.52 & 2.67 & 5.19 \\
\hline$x=13$ & 1105 & 35 & 0.57 & 6.52 & 12.08 & 1.13 & 1.22 & 2.35 \\
\hline$x \cdot 21 *$ & 1105 & 33 & 0.17 & 1.94 & 3.60 & 0.35 & 0.37 & 0.72 \\
\hline$x=22^{*}$ & 1115 & 31 & 0.09 & 1.04 & 1.93 & 0.19 & 0.20 & 0.39 \\
\hline$x-23^{* *}$ & 1115 & 31 & 0.06 & 0.76 & 1.40 & 0.13 & 0.14 & 0.27 \\
\hline
\end{tabular}

"Side plote, $/ 8$ in. thick, with shallow groove joint.

- Same os X-21 except for change in technique of applying flux.

step prevented a direct check on the chlorine content in the dissolved assembly solution.

The values of loss in $\Delta k / k$ were colculated on the bosis of a 3-by 9-slab loading arrangement of $140-9$ elements with a total poison cross section of $7700 \mathrm{~cm}^{2}$.

The results of the brazing tests show that the combination of higher brazing temperature, more shallow groove joint, and flooding of the side plate with an excess of flux reduced the amount of lithium, and presumably chlorine, by a factor of 21 . Attempts to braze at $1120^{\circ} \mathrm{F}$ were not successful becouse the braze metal alloyed excessively with the 25 -grade aluminum side plate at this temperature.

In the second phase of the investigation, the work was centered on the problem of developing a new braing flux that is essentially. free of lithium and chlorine. Several special fluxes prepared by Alcoa and Permolotem were tested, with unsuccessful results.

A new bromide-base flux, developed at ORNL, showed promise during initial testing. : The flux is prepared from a base mixture of 20 parts of barium bromide, 60 of calcium bromide, and 20 of sodium bromide, with 2 parts of either $\mathrm{CaCl}_{2}$ of $\mathrm{SrCl}_{2}$ and $1 \frac{1}{2}$ ports of $\mathrm{ZnCl}_{2}$ added. Testing is incomplete.

Design and Fabrication Studies to Improve the Al-to- $\mathrm{H}_{2} \mathrm{O}$ Ratio. Another approach to enhance the performance of the reactor is to alter the fuel element design to obtain a lower $V_{A 1}-t o-V_{H_{2}} \mathrm{O}$ ratio in the active core. Structurally, the present fuel element is over-designed for service in the MTR.
Study reveoled, however, that any contemplated design change is limited largely by the hydraulics of the present system; hence, only minor changes in the fuel element were considered. The modifications considered were guided, generally, by the following factors: (1) on $\mathrm{Al}-\mathrm{to}-\mathrm{H}_{2} \mathrm{O}$ ratio in the active core of less than 0.60 would be desirable; (2) the external dimensions of the fuel unit would remoin the same; (3) any fuel component member altered would not be substantially weakened structurally; (4) effects on water velocity and flow area would be investigoted; (5) no similar change would be made in the. fuel section of the shim control rod; (6) manufocturing cost would not in. crease.

The Al-to- $\mathrm{H}_{2} \mathrm{O}$ ratio of a single fuel element of the existing design $\left(3 / 16^{- \text {in. }}\right.$-thick side plote and 0.060 -in.-thick fuel plates) is 0.716 . This ratio increases slightly to 0.731 for the entire 3- by 9 -slab loading arrangement because of the additional aluminum in the four shim control rods.

The first change investigated was that of reducing the side-plate thickness from $3 / 16$ to $\frac{1}{8}$ inch. This lowered the Al-to- $\mathrm{H}_{2} \mathrm{O}$ ratio in the active lattice to 0.689 and increased $k$ eff by approximotely 1\%. The water flow ared increased $2.5 \%$

A dozen or more full-sized units of this design were successfully mocked up according to specifications, and no manufacturing difficulties were found. Subsequently, an enriched fuel element of the some design-was fobricoted and transferred for service in the LITR.

The second modification considered was that of decreasing the cladding on the fuel plate from 20 
to 15 mils. The combination of this change plus the thin-side plate drops the $\mathrm{Al}-\mathrm{to}-\mathrm{H}_{2} \mathrm{O}$ ratio in the active lattice to 0.569 , but the water gap in. creases from 117 to $128 \mathrm{mils}$.

No attempt was made to fabricate this particular unit because of the objectionable increase in water-gap thickness. Insteod, another fuel plate was added to the unit to bring the water-gap thickness back to 118 mils.

A 3- by 9-slab looding of these 19-plate elements hos an $\mathrm{Al}-\mathrm{to}-\mathrm{H}_{2} \mathrm{O}$ ratio of 0.600 , and, more importantly, it increases $k_{\text {eff }}$ by approximately $4 \%$. A portion of this gain, however, is due to the extra fuel present becouse of the added plate. The water-flow area is increased appreciably, that is, by $8.2 \%$.

It should be pointed out that this change does not materially weaken the fuel plate structurally, becouse the strength of the member is determined largely by the core alloy, which has been altered. The yield strength of annealed $2 \mathrm{~S}$-grade aluminum, for instance, is 5000 psi, whereas the $17 \%$ uranium-aluminum alloy has a yield strength of 9000 psi, based on a $0.2 \%$ off set at room, temperature.

The change does proportionately lower the omount of corrosion protection afforded. It is felt, however, that 15 mils of cladding would be more than adequate to protect the alloy core, which, by itself, exhibits fair corrosion resistance to water. Exomination of elements at ORNL after ten months of service in the Bulk Shielding Reactor failed to reveal any pitting type of attack or other corrosion phenomena. Service in static water, such as in the BSR, is more severe corrosion-wise than is the 30-fps water velocity condition that exists in the MTR.

Neutron-wise, it is certainly advantageous to replace oluminum with water. Furthermore, only 1 to 2 mils of aluminum is required to stop secondary neutron recoils.

Construction of the 19-plate element presents no manufacturing problems. Several full-sized units were prepared to establish the dimensions, and each unit met specifications in all respects. Also, an enriched fuel element was fabricated for service in the LITR.

The possibility of lowering the aluminum cladding to 10 mils was checked, but analysis revealed that the woter-flow orea would increase appreciably, that is, by $14.5 \%$.
Results of this and the other modifications discussed are summorized in Table 28. For com* parative purposes, cross-sectional views of the present, thin side-plate units and of the 19-plate fuel element are shown in Fig. 20.

The cladding was dropped in increments of 5 mils so that the commercially available, aluminum. stock goges could be used in the Alcladding operation. Actually, the cladding could be reduced in increments of, soy, 1 mil but this would require on additional rolling operotion and, hence, a greater cost per unit.

Proposed Change in the Lower Stainless Steel Section of the Shim Control Rod. It is proposed to replace the lower stainless steel section in the shim control rod with an aluminum extrusion to reduce fabrication cost. This lower beoring section is presently being fabricated from type 304 stainless steel flat stock that must be machined, welded, stress-relieved, and remachined prior to assembly. Replacing this item with a 635-grade aluminum extrusion would eliminate most of the costly labor operations.

The effect of this change on operational control, as well as on the mechanical stability of the new rod, was investigated by Gall. ${ }^{(3)}$ Changes in magnet release and drop time were calculated. Also, the stresses produced in the proposed aluminum member by shock on the rod when dropped with full water flow were checked by. two methods of analysis.

In conclusion, the study predicted that the change would: (I) decrease the fabrication cost by approximately $\$ 300$; (2) increase the drop plus magnet release time, under conditions of no woter flow, by 10\%; (3) produce a stress in the aluminum extrusion, caused by shock on the rod when dropped at full water flow, of less magnitude than exists in the bottom of the fuel section of the existing design. These predicted effects should be confirmed by condueting drop tests. Specifications on the new, eluminum, lower section are given in engineering drawing TD-3038.

MTR Replacement Fuel and Control Rod Elements. The 13 reactor loadings of standord $\left(3 / 16^{\circ}\right.$ in.-thick side plates and 60 -milsothick active plates) enriched fuel and control elements on order for calendar year 1952 were completed occording to specifications and shipped to Arco.

(3)W. R. Goll, MTR Shim Rod Aluminum Lower Beoring Section, ORNL, CF-52.11-216 (Nov. 29, 1952).

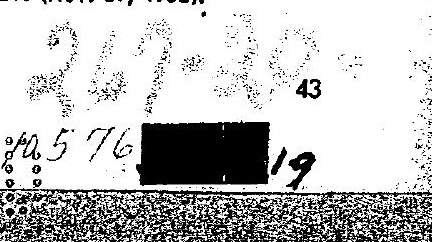




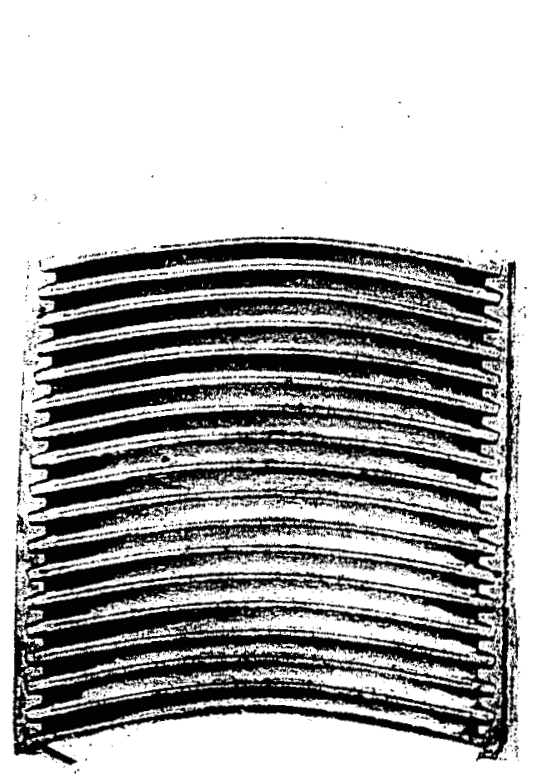

STANDARD 18-PLATE UNIT

Al TO $\mathrm{H}_{2} \mathrm{O}$ RATIO $=0.716$

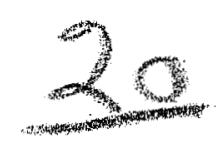

SECRET

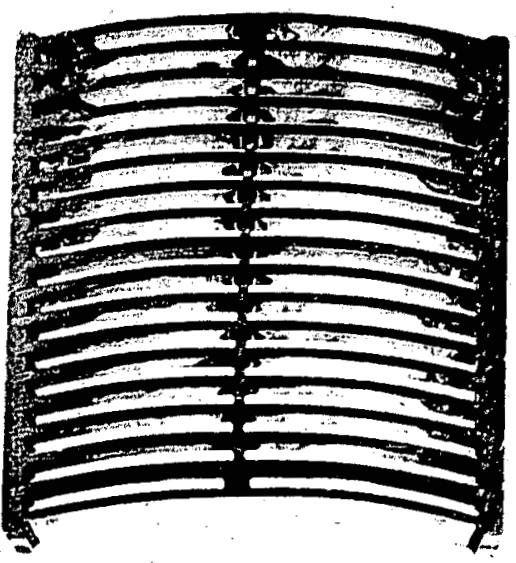

THIN SIDE - PLATE UNIT

Al TO $\mathrm{H}_{2} \mathrm{O}$ RATIO $=0.667$.

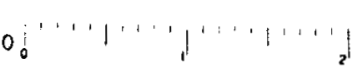

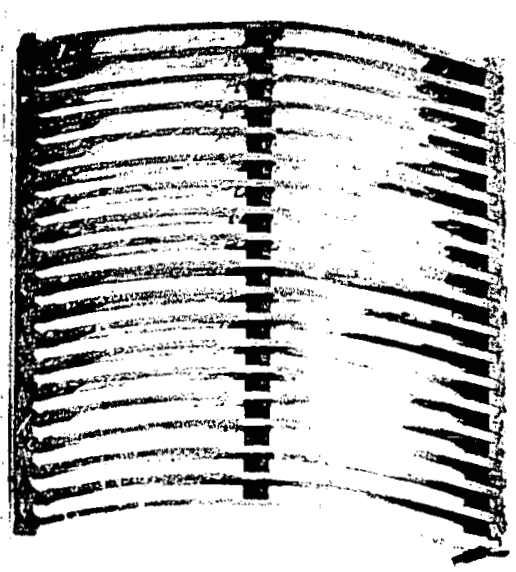

NEW 19 -PLATE UNIT

Al TO $\mathrm{H}_{2} O$ RATIO $=0.565$

Fig. 20. Cross-Sectional View of Present and Modified MTR Fuel Assemblies. 
Shipment on the last loading was made early in Decomber. In addition, three, spare, beryllium. cadmium control rods were fabricoted and for. warded.

An experimental looding of "sweetened" fuel elements was completed and shipped to the site in time for the scheduled February 1, 1953 reloading date. These units were fabricated according to specifications determined in discussions of the

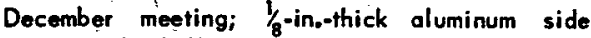
plates with shallow-groove joints were used, and the side plates were flooded with an excess of flux and brazed at a slightly higher temperature than that normally used.

Inspection reveoled that all 23 units were well within dimensional tolerance. The maximum deviation of water-gap spocing, for instance, was opproximotely $117 \pm 0.006$ mils, or to within $\pm 5 \%$ of the specified spacing and the overage deviation was about $\pm 3 \%$.

Fuel and Control Rod Elements. The initial Toóding of enriched uronium-aluminum alloy

TABLE 28. AREAS ANO VOLUMES OF MATERIALS IN THE MTR ACTIVE LATTICE FOR SEVERAL FUEL UNIT DESIGNS FOR THE 3. BY 9.\$LAB LATTICE $23.622 \mathrm{in.}(60 \mathrm{~cm})$ IN LENGTH

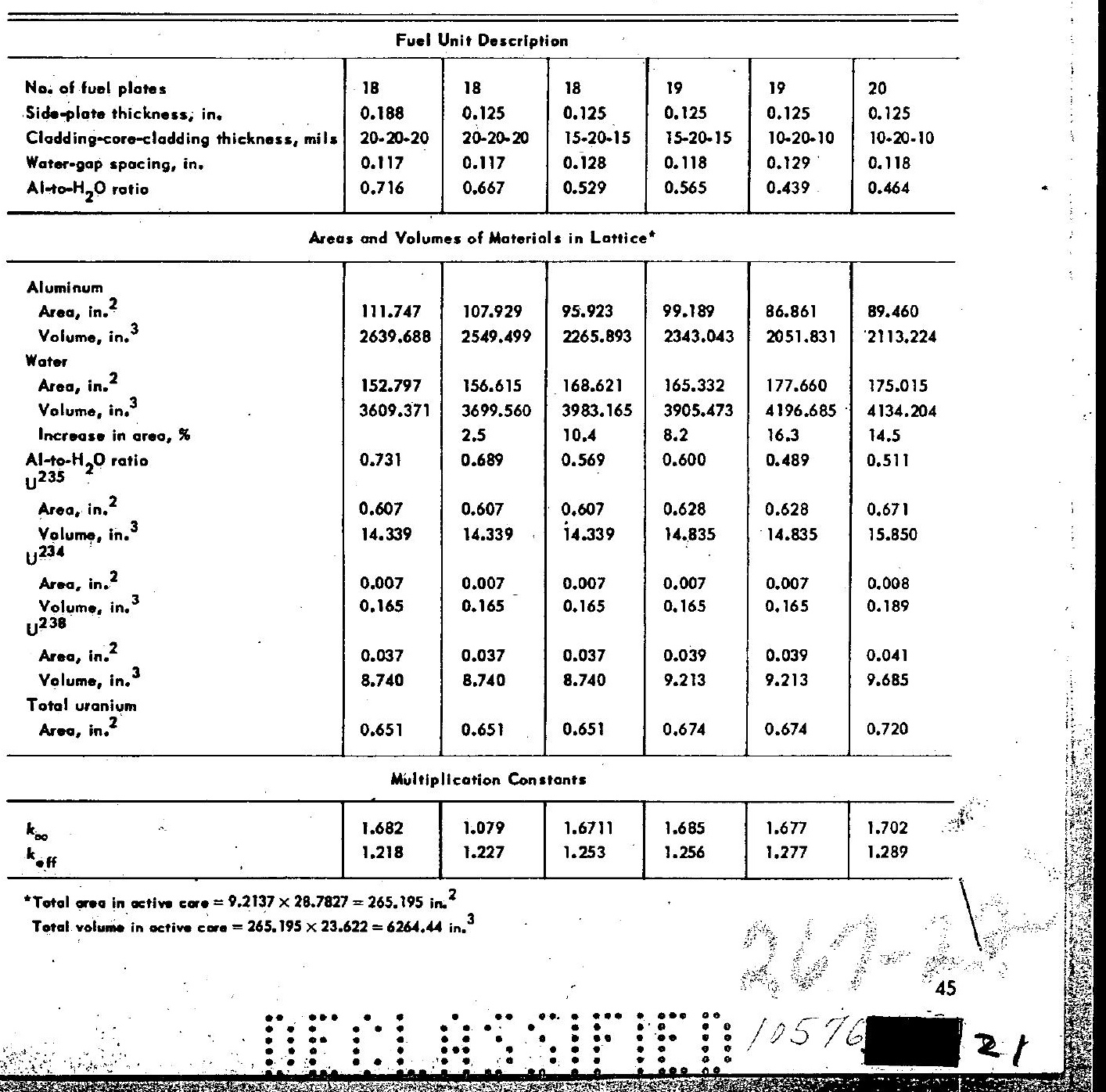




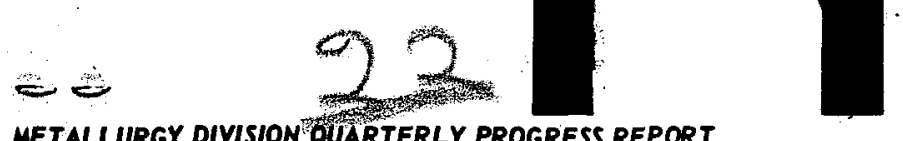

\section{METALLURGY DIVISION OUARTERLY PROGRESS REPORT}

finel elements

-s been manufactured and packoged for hipment. The loading consists of 30 of the standard, Bulk Shielding Reactor type of fuel element, 4 special fuel sections to house control rods, and 3 partial units containing $5,9$. and 14 active plates.

Unfortunately, delivery of the units has been delayed for over a month awaiting proper authorizotion for shipment.- The units are being stored in a voult for sofe keeping until authorization for shipment is recoived.

NA Alelad Uranium-Aluminum Alloy Plates. During the quarter, work was initiated on an order for 330 Alclad uraniumaluminum alloy plates for physical mockup tests of North American Aviation, in comection with the Uranium-Converter Reactor. Some trouble is being experienced in monufacturing these highouranium-content plates because of segregation during solidification of the alloy.

Ninespound melts of 26 to 27 int \% uranium were prepared by the direct alloying method and cast into tilted graphite molds. Analysis of samples taken from the casting revealed a 1 to $1.5 \%$ variation in uranium content from top to bottom of the castings, as well as some side-to-side segregation. Tolerance on the uranium content in eoch core is stringent, that is, $8.79 \pm 0.08$ groms.
Despite the segregation problem, on attempt is being made to obtain alloy cores that ore within the tolerence by using the density method. An experimental plot of density of the alloy os a function of composition has been obtained. This curve ogrees well with the theoretical curve, except that it is slightly displaced. By determining the density of the individual cores, the uranium content in each core can be obtained from the curve.

Methods of reducing segregation in this alloy are being investigated. Such expedients as chill casting in cast iron, thinner cross section molds, and $0.2 \%$ addition of titanium to the melt have failed to greatly reduce the amount of segregation encountered.

In preliminary tests, the possibility of preporing high-uranium-content plus aluminum compacts by powder metallurgy rechniques appears to be prom. ising. Cores of the MTR type, prepored by cold pressing a mixture of $\mathrm{U}_{3} \mathrm{O}_{8}$ and high-purity alu. minum powder, show densities of the order of 90 to $95 \%$ of theoretical. Uranium oxide in the form of $\mathrm{U}_{3} \mathrm{O}_{8}$ is preferred becouse of its stability to the thermal treatment required during the subse. quent jacketing and cladding operations that ore done in air. 